\title{
Anti-Helicobacter Pylori Activities of Shoya Powder and Essential Oils of Thymus Vulgaris and Eucalyptus Globulus
}

\author{
D. Esmaeili*,1, A. Mohabati Mobarez ${ }^{2}$ and A. Tohidpour ${ }^{2}$ \\ ${ }^{I}$ Applied Microbiology Research Center and Department of Medical Microbiology, Bqiyatallah University, Tehran, Iran \\ ${ }^{2}$ Department of Bacteriology, Faculty of Medical Sciences, Tarbiat Modares University, Tehran, Iran
}

\begin{abstract}
Background: Helicobacter pylori, an infective agent of more than $50 \%$ of the world population is prominent to be the main causative factor in the etiologies of chronic, active or type B gastritis, peptic and duodenal ulcer, gastric carcinoma, and mucosa-associated lymphoid tumors. A high prevalence of this bacterium in dental plaque is always reported. Pharmacological treatment of $\mathrm{H}$. pylori infections includes administration of 3-fold therapeutic regimens which are typically used to suppress $H$. pylori activity. However, antibiotic resistance frequently develops as a consequence of such treatment. Thus, searching for alternative therapies for $\mathrm{H}$. pylori infections is of special interest.
\end{abstract}

Materials and Methods: In this study, anti H. pylori activities of a traditional antimicrobial drug so-called Shoya and also essential oils of Thymus vulgaris and Eucalyptus globulus were investigated using antimicrobial analysis and serological screening methods.

Results: The agar dilution method results revealed the Shoya with the highest inhibitory effect against $H$. pylori. Also serological screening on tested mice showed a significant effect of this drug in lowering the sera amount of anti $H$. pylori specific IgA and IgG titers. Both of the essential oils showed different degrees of antibacterial effect against $H$. pylori.

Conclusion: The obtained results showed the antibacterial effect of Shoya powder and Essential oils from Thymus vulgaris and Eucalyptus globulus and purposes new therapeutical alternatives to control the $H$. pylori infection. Additional studies and clinical trials are necessary to approve the use of these data in health care and pharmacopeia systems.

Keywords: Helicobacter pylori, Shoya, Thymus vulgaris, Eucalyptus globulus.

\section{INTRODUCTION}

Helicobacter pylori is an extracellular gram-negative, spiral bacterium, which typically infects $40 \%$ of the adult population in developed countries and up to $90 \%$ in some developing countries $[1,2]$. Chronic gastritis is seen in nearly all individuals, $10-15 \%$ of whom will develop peptic ulcer disease or gastric cancer, the second most common cause of cancer mortality worldwide [3]. There is a high prevalence of $H$. pylori related gastric infections and dental plaque colonization in developing countries $[4,5]$. Current therapies for $H$. pylori are typically based on combination of a proton pump inhibitor and two antibiotics, but drawbacks include patient compliance, antibiotic resistance, and recurrence of infection. Since infection can cause life threatening diseases and therapy is neither $100 \%$ effective nor universally available, development of new therapies may be critically necessary [6].

The Shoya powder is a compound of five substances and acts as a strong antimicrobial drug which can be used for treatment of severe and mild infections. Essential oils (EOs)

*Address correspondence to this author at the Applied Microbiology Research Center, and Department of Medical Microbiology, Bqiyatallah University, Tehran, P.O Box. 14111-115, Iran; Tel: 098-21-22289941;

Fax: 098-21-26127258; E-mail: esm114@gmail.com have been shown to possess antibacterial, antifungal, antiviral, insecticidal and antioxidant properties [7-9]. Some oils have been used in food preservation [10], aromatherapy [11] and fragrance industries $[12,13]$. Therefore, it is reasonable to expect a variety of plant compounds in these oils with specific as well as general antimicrobial activity and antibiotic potential [14].

Thyme (Thymus vulgaris L.), a member of the Labiateae family, is an aromatic and medicinal plant of increasing importance in horticulture $[15,16]$. T. vulgaris, also known as common thyme, has long been used as a source of the essential oil (thyme oil) and other compounds (e.g. thymol, flavanoid, caffeic acid and labiatic acid) derived from the different parts of the plant $[17,18]$. The oil was reported to have antimicrobial effect on bacteria and fungi [19-21] carminative and expectorant [17] activities, most of which are mediated by thymol and carvacrol, as the phenolic components of the oil [22].

Eucalyptus is native to Australia. The genus Eucalyptus contains about 600 species. Of all the species, Eucalyptus globulus is the most widely cultivated in subtropical and Mediterranean regions [23]. Essential oils from Eucalyptus species are used in folk medicine and also widely used in modern cosmetics, food, and pharmaceutical industries [24, 25]. 
The present study was aimed to investigate the anti $H$. pylori activities of Shoya and also essential oils of Thymus vulgaris and Eucalyptus globulus.

\section{Preparation of Shoya Powder and Essential Oils}

The Shoya powder suspensions were prepared in 6 dilutions $\left(10^{-1}-10^{-6} \mathrm{mg} / \mathrm{ml}\right)$ using distilled water as the solvent. The herbs of T. vulgaris (garden Thyme) and the leaves of $E$. globulus collected and harvested at full flowering state and were authenticated by Dr. R. Omidbaigi, (Professor of botany at the college of agriculture, Tarbiat Modares University, Tehran, Iran). To isolate the oils, the collected materials of every treatment $(90 \mathrm{~g}$ three times) were subjected to hydrodistillation using a Clevenger type apparatus for 6 hours to produce essential oil according to the method recommended by the European Pharmacia [26]. The oils were dried over anhydrous sodium sulfate and stored in sealed vials at low temperature $\left(4^{\circ} \mathrm{C}\right)$ before analysis.

\section{Bacterial Strain and Culturing}

Helicobacter pylori ATCC 700392 and Helicobacter pylori clinical isolates were cultured in brucella agar [QUELAB incorporations, Canada. containing: peptone, yeast extract, dextrose, sodium chloride, agar and $\mathrm{PH}$ of 7.5 in each liter], plus $5 \%(\mathrm{v} / \mathrm{v})$ defibrinated sheep blood and $10 \%(\mathrm{v} / \mathrm{v})$ fetal calf serum.

\section{Antimicrobial Analysis}

The agar dilution method was used as approved by the NCCLS [27] with minor modifications: a series of two fold dilutions was prepared for each of the Thymus and Eucalyptus essential oils as the following: $0.03 \%(\mathrm{v} / \mathrm{v}), 0.05 \%(\mathrm{v} / \mathrm{v})$, $0.07 \%(\mathrm{v} / \mathrm{v})$ and $0.09 \%(\mathrm{v} / \mathrm{v})$ in the enriched brucella agar medium. To enhance the essential oil solubility, $0.5 \%(\mathrm{v} / \mathrm{v})$ of tween-20\% was added into agar. The Shoya powder suspensions were prepared in serial dilutions and spread into mediums. Inoculated plates with $5 \mu \mathrm{l}$ of $H$. pylori containing about $5 \times 10^{5}$ of the microorganism were incubated in a microaerophlic jar system $\left(5 \% \mathrm{O}_{2}, 10 \% \mathrm{CO}_{2}\right.$ and $\left.85 \% \mathrm{~N}_{2}\right)$ at $37^{\circ} \mathrm{C}$ for $72 \mathrm{~h}$ and then visible colonies formed on the plates were enumerated. The MIC values were defined as the lowest concentration of Shoya and EOs at which no colony of the test bacteria was detected. Finally, the agar disk diffusion method was used to assess the anti $H$. pylori activity of Shoya suspensions. $100 \mu 1$ of each suspension containing about $10^{8}$ cells/ $\mathrm{ml}$ was spread on enriched brucella agar mediums. Six mm filter papers containing 10-12 $\mu$ l from any of suspensions were placed on agar surface. Inoculated plates were incubated for $72 \mathrm{~h}$ as described above and then the inhibition zones were measured in diameters. Each test was repeated as duplicate.

\section{Immunization Assay}

In order to analyze the immunological effect of Shoya powder on antibody production, a group of 20 mice showing very low titers of IgA and IgG (T0) against $H$. pylori were first challenged orally with $H$. pylori and evaluated after two weeks to analyze their specific anti $H$. pylori IgA and IgG titers (T1) in sera using a mouse anti H. pylori IgA and IgG serotyping kit (Roche bichemicals, Germany). These were then treated orally with the Shoya solution for two weeks and were tested for the final titers (T2) of $\operatorname{IgA}$ and $\operatorname{IgG}$ to assess the potential therapeutic and eradicative effect of Shoya powder against $H$. pylori.

\section{Analyzing Gastric Tissue}

Finally, the mice stomachs were dissected by gastrectomy and divided into longitudinal strips to assess the presence of $H$. pylori using a rapid urease broth test kit (Chemy Enzyme chemicals, Iran).

$\mathrm{T}^{\mathrm{a}}$ : Titers of specific anti-H. pylori $\operatorname{IgA}$ and $\operatorname{IgG}$ in tested mice sera before challenging with $H$. pylori. $\mathrm{T}^{\mathrm{b}}$; Titers of specific anti-H. pylori $\operatorname{IgA}$ and $\operatorname{IgG}$ in mice sera two weeks after challenging with $H$. pylori. $\mathrm{T}^{\mathrm{c}}$; final titers of IgA and IgG in mice infected with $H$. pylori and treated two weeks with Shoya suspension. Antibody levels are shown as Mean \pm SD of ODR per microgram of protein units for anti H.pylori IgG and IgA.

\section{RESULTS}

\section{Antimicrobial Assay}

The MIC results for three tested compounds are shown in Tables $\mathbf{1}$ and $\mathbf{2}$ which show the antibacterial effect of Shoya powder and essential oils of $\mathrm{T}$. vulgaris and E. globulus against H. pylori ATCC 700392 using agar dilution method. Shoya powder exhibited relatively a very high anti $H$. pylori activity $\left(10^{-5} \mathrm{mg} \mathrm{ml}^{-1}\right)$ (Table 2). Anti $H$. pylori activity in $T$. vulgaris and E. globulus were 10.8 and $46.4(\mu \mathrm{g} / \mathrm{ml})$ respectively.

Table 1. Antimicrobial Activity of Thymus Vulgaris and Eucalyptus Globulus Essential Oils Serial Dilutions Against H. Pylori ATCC 700392

\begin{tabular}{|l|l|l|l|}
\hline $\begin{array}{c}\text { H. Pylori } \\
\text { Growth }\end{array}$ & $\begin{array}{c}\text { Eucalyptus } \\
\text { Globules } \\
(\boldsymbol{\mu g} / \mathbf{m l})\end{array}$ & \multicolumn{1}{|c|}{$\begin{array}{c}\text { H. pylori } \\
\text { Growth }\end{array}$} & $\begin{array}{c}\text { Thymus } \\
\text { Vulgaris } \\
(\boldsymbol{\mu g} / \mathrm{ml})\end{array}$ \\
\hline \hline+ & 5.8 & + & 5.4 \\
\hline+ & 11.6 & - & 10.8 \\
\hline+ & 23.2 & - & 21.2 \\
\hline- & 46.4 & - & 42.4 \\
\hline- & 92.8 & - & 84.8 \\
\hline
\end{tabular}

Table 2. Antimicrobial Activity of Shoya Powder Suspensions Against H. Pylori ATCC 700392

\begin{tabular}{|l|l|l|}
\hline $\begin{array}{c}\text { Inhibition Zone } \\
(\mathbf{m m})\end{array}$ & \multicolumn{1}{|c|}{ Visible Growth } & \multicolumn{1}{|c|}{$\begin{array}{c}\text { Suspension Dilutions } \\
(\mathbf{m g} / \mathbf{m l})\end{array}$} \\
\hline \hline 16 & - & $1 / 10\left(10^{-1}\right)$ \\
\hline 16 & - & $1 / 100\left(10^{-2}\right)$ \\
\hline 15.5 & - & $1 / 1000\left(10^{-3}\right)$ \\
\hline 15 & - & $1 / 10000\left(10^{-4}\right)$ \\
\hline 14 & - & $1 / 100000\left(10^{-5}\right)$ \\
\hline 12 & + & $1 / 1000000\left(10^{-6}\right)$ \\
\hline
\end{tabular}




\section{MATERIALS AND METHODS}

\section{Immunization Assay}

The Shoya powder suspension treatments against challenged mice could apparently reduce the specific anti $H$. $p y$ lori IgA and IgG. Table 3 shows the tested mice immunization analysis results obtained during 4 months of screening.

\section{Rapid Urease Broth Test}

This test detects Helicobacter pylori (H. pylori) by finding the presence of urease. Urease is an enzyme produced by H. pylori. Urease broth is a differential medium that tests the ability of an organism to produce an exoenzyme, called urease that hydrolyzes urea to ammonia and carbon dioxide. The broth contains two $\mathrm{pH}$ buffers, urea, a very small amount of nutrients for the bacteria, and the $\mathrm{pH}$ indicator phenol red. Phenol red turns yellow in an acidic environment and fuchsia in an alkaline environment. If the urea in the broth is degraded and ammonia is produced, an alkaline environment is created, and the media turns pink.

\section{DISCUSSION}

There are problems with current antibacterial treatments against $H$. pylori such as multidrug resistance, high ex- penses, drug interventions, poor satisfaction, side effects and their impact on the normal intestinal flora [6] which together highlight the need for alternative therapeutic methods such as traditional medicine. Yuan-Chuen Wang et al reported anti $H$. pylori activity of Plumbago zylanica L. with MIC of 0.32 to $1.28 \mathrm{mg} \mathrm{ml}^{-1}$ [28]. Cellini et al., reported that the phosphate extract of garlic possesses anti $H$. pylori activity against 19 strains of $H$. pylori with MIC ranging from 2-5 $\mathrm{mg} \mathrm{ml}^{-1}$ [29]. The anti $H$. pylori activity of the methanol extract of Myroxylon peruiferum, a medicinal plant of Brazil was $62.5 \mathrm{mg} \mathrm{ml}^{-1}$ [30]. The anti H. pylori effect of $22 \mathrm{mi}-$ cromyctes was studied against one standard strain and 11 clinical isolates of H. pylori. Penicillium ochlochloron and Penicillium funiculosum have been proven as the most active fungi against this microorganism (MIC $3.9 \mathrm{mg} \mathrm{ml}^{-1}$ ) [31]. Our findings through this research significantly indicate Shoya powder as a potential lead compound of a novel class of $H$. pylori inhibitors where it shows a very high anti $H$. pylori effect (MIC $10^{-6} \mathrm{mg} \mathrm{ml}^{-1}$ ). More ever, it is not toxic, and is widely available as a low price traditional drug compound.

Determine the antibodies against $H$. pylori yields in a relatively simple diagnosis, especially with kits that can be used to perform this method and are now being widely and commercially available [32].

Table 3. Serological Analysis of Variable Titers of IgA and IgG in Mice Challenged with H. Pylori and Treated with Shoya During 4 Months

\begin{tabular}{|c|c|c|c|c|c|c|}
\hline \multicolumn{2}{|c|}{$\mathrm{T}^{\mathrm{c}}(\mu \mathrm{g} / \mathrm{ml})$} & \multicolumn{2}{|c|}{$\mathrm{T} 2^{\mathrm{b}}(\mu \mathrm{g} / \mathrm{ml})$} & \multicolumn{2}{|c|}{$\mathrm{T} 1^{\mathrm{a}}(\mu \mathrm{g} / \mathrm{ml})$} & \multirow{3}{*}{ Tested Mice } \\
\hline \multicolumn{2}{|c|}{$\mathbf{T 3}^{\mathrm{c}}$} & \multicolumn{2}{|c|}{$T 2^{\mathrm{b}}$} & \multicolumn{2}{|c|}{$\mathbf{T 1}^{\mathrm{a}}$} & \\
\hline IgG & IgA & IgG & $\operatorname{IgA}$ & IgG & $\operatorname{IgA}$ & \\
\hline $4 \pm 0.23$ & $5 \pm 0.27$ & $21 \pm 0.88$ & $30 \pm 0.12$ & $3 \pm 1.23$ & $6 \pm 1.34$ & 1 \\
\hline $2 \pm 1.21$ & $3 \pm 1.61$ & $18 \pm 0.97$ & $27 \pm 0.39$ & $2 \pm 1.11$ & $5 \pm 1.29$ & 2 \\
\hline $2 \pm 2.13$ & $8 \pm 1.81$ & $7 \pm 2.11$ & $35 \pm 0.99$ & $3 \pm 0.78$ & $7.5 \pm 1.2$ & 3 \\
\hline $2 \pm 1.33$ & $4 \pm 2.20$ & $7 \pm 1.21$ & $15 \pm 1.11$ & $4 \pm 0.93$ & $8 \pm 1.02$ & 4 \\
\hline $2 \pm 0.87$ & $3 \pm 1.23$ & $8 \pm 1.29$ & $12 \pm 1.21$ & $2 \pm 1.24$ & $3.5 \pm 1.48$ & 5 \\
\hline $2 \pm 1.12$ & $3 \pm 2.48$ & $7 \pm 2.11$ & $13 \pm 1.43$ & $2.5 \pm 1.78$ & $4 \pm 1.11$ & 6 \\
\hline $2 \pm 0.89$ & $3.5 \pm 1.11$ & $6 \pm 0.22$ & $17 \pm 1.65$ & $3 \pm 2.13$ & $5 \pm 1.42$ & 7 \\
\hline $3 \pm 0.79$ & $9 \pm 7.40$ & $15 \pm 1.15$ & $45 \pm 0.34$ & $4 \pm 2.53$ & $9 \pm 1.63$ & 8 \\
\hline $3 \pm 1.26$ & $4 \pm 2.01$ & $15 \pm 1.10$ & $19 \pm 0.84$ & $5 \pm 2.36$ & $6.5 \pm .12$ & 9 \\
\hline $2.5 \pm 2.01$ & $3.5 \pm 1.22$ & $16 \pm 1.17$ & $23.5 \pm 0.38$ & $6 \pm 0.79$ & $7 \pm 1.43$ & 10 \\
\hline $3 \pm 0.96$ & $4 \pm 2.43$ & $16 \pm 2.11$ & $28.5 \pm 1.41$ & $5 \pm 0.63$ & $9 \pm 2.18$ & 11 \\
\hline $3 \pm 1.24$ & $3 \pm 0.75$ & $17 \pm 1.19$ & $29 \pm 1.32$ & $3 \pm 2.16$ & $4 \pm 1.21$ & 12 \\
\hline $3.5 \pm 1.09$ & $4 \pm 1.88$ & $11 \pm 1.32$ & $12 \pm 1.65$ & $2.5 \pm 2.32$ & \pm 2.423 & 13 \\
\hline $2.5 \pm 2.11$ & $4 \pm 1.37$ & $12 \pm 0.86$ & $14 \pm 1.67$ & $2 \pm .94$ & $3.5 \pm 0.89$ & 14 \\
\hline $2.5 \pm 1.31$ & $3 \pm 2.17$ & $12 \pm 1.53$ & $17 \pm 2.22$ & $2 \pm 1.37$ & $3 \pm 0.96$ & 15 \\
\hline
\end{tabular}

$\mathrm{T}^{\mathrm{a}}$ : Titers of specific anti-H. pylori IgA and IgG in tested mice sera before challenging with $H$. pylori. $2^{\mathrm{b}}$; Titers of specific anti-H. pylori IgA and IgG in mice sera two weeks after challenging with $H$. pylori. $\mathrm{T}^{\mathrm{c}}$; final titers of $\operatorname{IgA}$ and $\operatorname{IgG}$ in mice infected with $H$. pylori and treated two weeks with Shoya suspension. Antibody levels are shown as Mean \pm SD of ODR per microgram of protein units for anti H.pylori $\operatorname{IgG}$ and $\operatorname{IgA}$. 
Evaluating the effect of Shoya powder suspensions on specific antibody production in human and mice cases clearly resulted in a meaningful decrease in titers of specific anti H. pylori $\operatorname{IgA}$ and $\operatorname{IgG}$ which can be referred to the therapeutic effect of this traditional drug. Essential oils are considered as possible sources of new antimicrobial agents especially against bacterial pathogens [33]. Many studies have investigated the antibacterial activity of essential oils from T. vulgaris and E. globulus against different pathogens [34]. Their antimicrobial activity is mainly attributed to the presence of some active constituents in their EOs together with their hydrophobicity which enables them for rupturing cell membranes and intrastructures [35]. In this study, EOs of T. vulgaris and E. globulus were used to assess their antibacterial activity against $H$. pylori ATCC 700392 by inserting some minor changes to the NCCLS recommended agar dilution method that have been originally developed for analyzing the conventional antimicrobial agents activity, so it could be used to analyze plant extracts and essential oils for their antimicrobial activity [36]. The obtained results confirm that EO from $T$. vulgaris showed better inhibitory effect against $H$. pylori than EO from E. globulus. Previous studies performed in Pakistan [37, 38] India [39], Nigeria [40] and Venezuela [41] indicate positive correlation between oral and gastric $H$. pylori colonization. It is implicated that oral cavity may be the first colonization site which then infects the gastric mucosa.

According to difficulties for eradication of $H$. pylori Due to the disadvantages of antibacterial treatments and presence of $H$. pylori in mouth as a secondary reservoir [42] and also the obtained results of this research, it is recommended to combine the triple drug treatment regime with Shoya as a mouth washing solution or as a tooth paste ingredient or together with EOs of T. vulgaris and E. globulus in order to control the $H$. pylori presence specially for eradication of $H$. pylori in dental plaques and related diseases. Additional clinical research and trials are necessary to completely confirm the above results for medical purposes. As mentioned above, dental plaques play a critical role as important reservoirs for H. pylori, therefore this bacteria will be able for colonization in dental plaque and inside oral yeasts where is protected from antibacterial drugs effects. In this study using Shoya powder against $H$. pylori resulted in complete eradication of this bacterium which can be effective enough to reduce the rate of infection transmission from mouth to gastric.

\section{CONFLICT OF INTEREST}

The author(s) confirm that this article content has no conflicts of interest.

\section{ACKNOWLEDGEMENT}

We are so thankful of Dr. Graham (University of Washington, Seattle, Washington. Baylor College of Medicine, Houston, Texas. USA) and Dr. Kuster (the Laboratory of Gastroenterology at the ErasmusMC, Rotterdam, Netherlands) for their warmly granted helps and advices.

\section{REFERENCES}

[1] Suerbaum S, Michetti P. Helicobacter pylori infection. N Engl J Med 2002; 347:1175-86.
[2] Del Giudice G, Covacci A, Telford Jl, Montecucco C, Rappuoli R. The design of vaccines against Helicobacter pylori and their development. Annu Rev Immunol 2001; 19: 523-63.

[3] Peek RM Jr, Blaser MJ. Helicobacter pylori and gastrointestinal tract adeno- carcinomas. Nat Rev Cancer 2002; 2: 28-37.

[4] Butt AK, Khan AA, Bedi R. Helicobacter pylori in dental plaque of Pakistanis. J Int Acad Periodontol 1999; 1: 78-82

[5] Qureshi H, Ahmed W, Arain G, Syed S, Mehdi I, Alam SE. Correlation of histology, CLO, dental plaque and saliva in patients undergoing upper GI endoscopy. Am J Gastroenterol 1999; 94: 861-2.

[6] Lucey DR, Clerici M, Shearer GM. Type 1 and Type 2 cytokine dysregulation in human infectious, neoplastic, and inflammatory disease. Clin Microbiol Rev 1996; 9:532-62.

[7] Burt SA. Essential oils: their antibacterial properties and potential applications in foods: a review. Int J Food Microbiol 2004; 94: 223-53.

[8] Kordali S, Kotan R, Mavi A, Cakir A, Ala A, Yildirim A. Determination of the chemical composition and antioxidant activity of the essential oil of Artemisia dracunculus and of the antifungal and antibacterial activities of Turkish Artemisia absinthium, Artemisia dracunculus, Artemisia santonicum, and Artemisia spicigera essential oils. J Agric Food Chem 2005; 53: 9452-8.

[9] Sylvestre M, Pichette A, Longtin A, Nagau F, Legault J. Essential oil analysis and anticancer activity of leaf essential oil of Croton flavens L. from Guadeloupe. J Ethnopharmacol 2006; 103:99-102.

[10] Faid M, Bakhy K, Anchad M, Tantaoui-Elaraki A. Alomondpaste: Physicochemical and microbiological characterizations and preservation with sorbic acid and cinnamon. J Food Prod 1995; 58: 54750 .

[11] Buttner MP, Willeke K, Grinshpun SA. Sampling and analysis of airborne microorganisms. In: Hurst CJ, Knudsen GR, McInerney MJ, Stetzenbach LD, Walter MV, Eds. Manual of Environmental Microbiology. Washington, DC: ASM Press 1996; pp. 629-40.

[12] Van de Braak SAAJ, Leijten GCJJ. Essential oils and oleoresins: A survey in the netherlands and other major markets in the european union. Rotterdam: CBI, Centre for the Promotion of Imports from Developing Countries, 1999; p. 116.

[13] Milhau G, Valentin A, Benoit F, et al. In vitro antimicrobial activity of eight essential oils. J Essent Oil Res 1997, 9: 329-33.

[14] Darokar MP, Mathur A, Dwivedi S, Bhalla R, Khanuja SPS, Kumar S. Detection of antibacterial activity in the floral petals of some higher plants. Curr Sci 1998; 75:187.

[15] Inouye S, Abe S, Yamaguchi H, Asakura M. Comparative study of antimicrobial and cytotoxic effects of selected essential oils by gaseous and solution contacts. Int J Aromather 2003; 13: 33-41.

[16] Kurita N, Miyaji M, Kurane V, Takahara Y, Ichimura K. Antifungal activity and molecular orbital energies of aldehyde compounds fom oils of higher plants. Agric Biol Chem 1979; 43: 2365-71.

[17] Leung AY, Foster S. Encyclopedia of common natural ingredients used in food, drugs, and cosmetics. New York: John Wiley \& Sons 1996; pp. 222-4.

[18] Al-Shuneigat J, Cox SD, Markham JL. Effects of a topical essential oil-containing formulation on biofilm-forming coagulase-negative staphylococci. Lett Appl Microbiol 2005, 41: 52-5.

[19] De Bouchberg MS, Allegrini J, Bessiere C, Attisto M, Passet J, Granger R. Properties microbiologiques de bciles essentielles de chimotypes de Thymus vulgaris Linnaeus. Rivista Italiana Essenza Profumi Piante Officinai Aromi Sapingi Cosmetici 1976; 58: 52736.

[20] Horne D, Holm M, Oberg C, Chao S, Young PG . Antimicrobial effects of essential oils on Streptococcus pneumonia. J Essent Oil Res 2001; 13: 387-92

[21] Chao SC, Young DG, Oberg C. Screening for inhibitory activity of essential oils on selected bacteria, fungi and viruses. J Essent Oil Res 2000;12:639-49.

[22] Meister A, Bernhardt G, Christoffel V, Buschauer A. Antispasmodic activity of Thymus vulgaris extract on the isolated guineapig trachea: discrimination between drug and ethanol effects. Planta Med 1999 65: 512-6.

[23] Gray AM, Flatt PR. Anti-hyperglycemic actions of Eucalyptus globulus (eucalyptus) are associated with pancreatic and extrapancreatic effects in mice. J Nutr 1998; 128: 2319-23.

[24] Gomes-Carneiro, Felzenszwalb MR, Paumgartten I. Mutagenicity testing (+/-)-camphor, 1, 8-cineole, citral, citronellal, (-)- menthol and terpineol with the Salmonella/microsome assay. Mutat Res 1998; 416: 129-36. 
[25] Trigg JK. Evaluation of a eucalyptus-based repellent against Anopheles spp. in Tanzania. J Am Mosq Control Assoc 1996; 12: 243-6.

[26] Calamari D, Zuccato E, Castiglioni S, Bagnati R, Fanelli R. Strategic survey of therapeutic drugs in the rivers Po and Lambro in northern Italy. Environ Sci Technol 2003; 37: 1241-8

[27] NCCLs. Methods for dilution antimicrobial susceptibility tests for bacteria that grow aerobically. Approved Standard. $6^{\text {th }}$ ed. NCCLS document M7-A6 2004.

[28] Wang Y, Huang T. Anti-Helicobacter pylori activity of PLumbago zeylanica L. FEMS Immunol. Med Microbiol 2005; 43: 407-12.

[29] Cellini L, Campli ED, Masulli M, Bartolomeo SD, Allocati N. Inhibition of Helicobacter pylori by garlic extracts (Allium sativum). FEMS Immunol Med Microbiol 1996; 13: 277-9.

[30] Ohsaki A, Takashima J, Chiba N, Kawamura M. Microanalaysis of selective potent anti-Helicobacter pylori compound in a Brazilian medicinal plant, Myroxylon peruiferum and the activity of analogues. Bioorg Med Chem Lett 1999; 9:1109-12.

[31] Stamatis G, Rancic A, Sokovic M, et al. In vitro inhibition of Helicobacter pylori by Micromycetes. FEMS Immunol Med Microbiol 2005;45: 71-4.

[32] Azuma T, Kato T, Hirai M, Ito S, Kohli Y. Diagnosis of Helicobacter pylori infection. J Gastroenterol Hepatol 1996; 11: 662-9.

[33] Mitscher LA, Drake S, Gollapudi SR, Okwute SK. A modern look at folkloric use of anti-infective agents. J Nat Prod 1987; 50: 102540 .

[34] Cimanga K, Kambu K, Tona L, et al. Correlation between chemical composition and antibacterial activity of essential oils of some aromatic medicinal plants growing in the Democratic Republic of Congo. J Ethnopharmacol 2002; 79: 213-20.

[35] Sikkema J, Debont JAM, Poolman B. Interactions of cyclic hydrocarbons with biological membranes. J Biol Chem 1994; 269: 8022 8.

[36] Hammer KA, Carson CF, Riley TV. Antimicrobial activity of essential oils and other plant extracts. J Appl Microbiol 1999; 86: 985-90.

[37] Butt AK, Khan AA, Khan AA, Izhar M, Alam A, Shah SW. Correlation of Helicobacter pylori in dental plaque and gastric mucosa of dyspeptic patients. J Pak Med Assoc 2002 ; 52: 196-200.

[38] Siddiq M, Rehman H, Mahmood A. Evidence of Helicobacter pylori infection in dental plaque and gastric mucosa. J Coll Physicians Surg Pak 2004; 14: 205-7.

[39] Anand PS, Nandakumar K, Shenoy KT. Are dental plaque, poor oral hygiene and periodontal disease associated with Helicobacter pylori infection? J Periodontol 2006; 77: 692-8.

[40] Ogunbodede EO, Lawal OO, Lamikanra A, Okeke IN, Rotimi O, Rasheed AA. Helicobacter pylori in the dental plaque and gastric mucosa of dyspeptic Nigerian patients. Trop Gastroenterol 2002; 23: 127-33.

[41] Berroteran A, Perrone M, Correnti M, et al. Detection of Helicobacter pylori DNA in the oral cavity and gastroduodenal system of a Venezuelan population. J Med Microbiol 2002; 51: 764-70.

[42] Oshowo A, Tunio M, Gillam D, et al. Oral colonization is unlikely to play an important role in Helicobacter pylori infection. Br J Surg 1998; 85: 850-2.

This is an open access article licensed under the terms of the Creative Commons Attribution Non-Commercial License (http://creativecommons.org/licenses/ by-nc/3.0/) which permits unrestricted, non-commercial use, distribution and reproduction in any medium, provided the work is properly cited. 